\title{
SOCIO-ECONOMIC IMPACTS OF DAIRY COOPERATIVE
}

\author{
Balak Chaudhary* and Mukul Upadhyaya**
}

\begin{abstract}
A study was conducted in Adarsha Milk Producer Dairy Cooperative, Mahuli, of Saptari district to find out socio-economic impact of dairy cooperative during May 2008 to Dec.2008. Response from 224 milk producing farmers were randomly collected, stored and analysed using Microsoft excel program. Different sources of income have been recorded and analysed with major category as main crop, cash crop, dairy goat farming and service in organizations. Among them, dairy was found to be the highest income contributor (55\%) to the rural farmers. Moreover, dairy was found to be the symbol of pride, prestige and religious priority for the studied community.
\end{abstract}

Key words: Dairy, cooperative, socio-economic impact.

\section{INTRODUCTION}

The history of cow started with entry of cows in Nepal by Gopal Bansi probably 4000 years ago. In modern era, the first step in this direction was taken by Prime Minister of Nepal His Excellency Jung Bahadur Rana in 1850 A.D. (Upadhyaya et al, 2001). Today, dairy farming is the second most important income-generating element which contributes 2/3rd to Agriculture Gross Domestic Product (CBS, 2010) of the nation. It is the livelihood of more than 80 percent of rural people who do not have enough land for other agricultural activities. Milk being a perishable commodity, cannot be marketed individually and this inconvenience gives rise to Milk Producers Cooperatives (MPC). Dairy cooperatives are defined as the group of at least 25 milk producing farmers who deliver milk to the consumers or to the processors. The main aim of the cooperatives is to provide service and generate income collectively. Income depends on demand and supply of milk. Demand of milk is increasing especially in urban area along with the rapid growth of population. Dairy cooperatives are important channels of milk production and supply that leads to generating income source for the rural people. Milk producing farmers are assumed to have 90876 in the country. Out of the total milk producing farmers, 59841 are male and 31035 are female. It has been estimated

\footnotetext{
${ }^{*}$ Mr. Chaudhary is Director (Technical), National Dairy Development Board, Hariharbhawan

** Mr.Upadhyaya is veterinary office, Veterinary Public Health Office, Tripureshwor
} 
that NRs.9, 000, 000 enters daily to the rural from the urban area as a result of carrying dairy business.

It will give higher socio-economic impact on the society when a number of farmers in the same village are doing dairy farming. This has been shown on many occasions where the opening of a plant with regular collection and payment has improved the standard of living not only of the farmer but also of other people living in the area (FAO, 1972). Income from milk and livestock farming have made people culturally changed which can be seen from their good housing, hygienic toilet, bio-plant, education, employment and credit flow.

\section{Adarsha Dairy Cooperative, Mahuli, Saptari}

Adarsha Dairy Cooperative is in Bakhdhuwa VDC, Saptari district of Nepal. People, who concerned to dairy cooperative, migrated from Khotang (1971), Meghalaya (1988) and different part of Nepal. In the beginning they had no land, therefore they have livestock farming. Biratnagar Milk Supply Scheme (BMSS) established milk collection depot at Mahuli. The people from Meghalaya had some idea of dairy farming, which realized the need of the pasture and fodder for the livestock animal. The then Ganga Prasad Sharma of Managing Director of Krishi Vikash Bank, Rajbiraj and Subas Rai, cooperative Officer, Rajbiraj helped to form cooperative and the result was established in the form of cooperative at May 16, 1993.

In 1971, there were 60-70 people with 10-11 households. After 3 years, families grew up and became 35 households. Presently, there are about 400 households of about 6000 people covered with 100 Bigha of land comprising about 5-10 Kattha land of every household. This dairy cooperative covers 4 VDCs likewise Bakdhuwa, Jandol, Theliya and Kanchanpur and collects about 4000 litre of milk daily at flush season. Livestock animals are rearing stall-feeding covering about 600 hector of community forestry handle by 400 households. The Mahuli VDC has fertile land, however there is scarcity of irrigation therefore major income of the people are livestock farming. There are available of Primary School, Middle School, Polish Office, Post Office and Secondary Boarding School for the convenient of the people.

\section{Socio-Economic Relation by Dairy Farming}

Livestock farming specially dairying is backbone of income for the villagers. Animal and animal by-products keep economic value such as animal sale, milk cash, fertilizer, draught, and biogas and broadly speaking, it has socio-economic importance as outlined in Chart 1. 


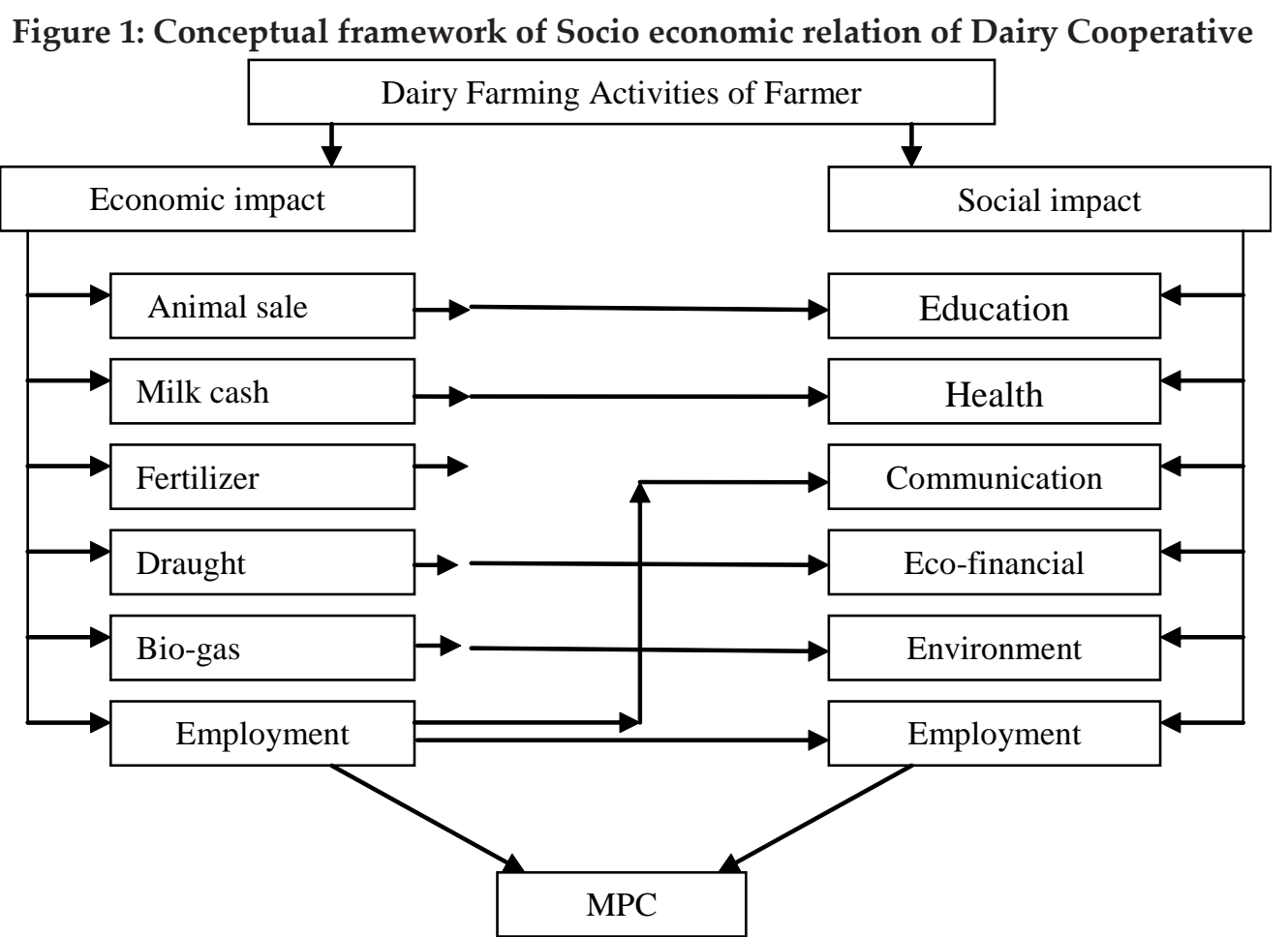

Two types of impact are categorised in Figure-1, which are economic and social impacts. Economic impact deals with the financial achievement from dairying of individual and the social impact deals with their links in the achievement of the whole society. All the economic impacts as shown in chart 1 are inter-linked in terms of social impact such as income from sale of animals, milk cash, fertilizer, draught and biogas. They will contribute for education and health leading to better life. Some of the components in the conceptual framework can be described as below.

Animal Sale: Farmers of dairy cooperative have local and cross breed of dairy animals. With regards to cattle, heifers are sold to the customers at market price and less productive and or old animals are culled at low price. However, few calves are sold as per demand of the customer for the purpose of natural service.

Milk Cash: Milk is considered as a cash product for farmer as it is being sold morning and evening daily. Farmers deliver their milk at Milk Producers Cooperatives (MPC) and get the milk cash as per quality parameter of fat and SNF and volume basis at each fortnight. 
Fertilizer: Farmyard manure is being prepared by the slurry from shed and dung of animals. This fertilizer makes the field more fertile rather than chemical fertilizers.

Draught: Ox and male buffalo is source for pulling cart and tilling the field. Farmers cannot complete their field without their help.

Biogas: Biogas is the alternate source of energy for cooking and lightning the village. Dung is decomposed and changed in the form of methane which is inflammable and this can be seen in houses of some of the dairy farmers of Mahuli.

Employment: Dairy farming creates labour for completion of daily work. Farmers have not any alternate options except dairy farming in Mahuli. Therefore, this farming has created the employment in each household.

All the above economic impacts are inter-linked in terms of social aspect such as income from animal sale, milk cash, fertilizer, draught, and biogas finally help to afford in education and health. Education makes individual educated and its influences in society make them civilized and healthy. Likewise, agro by-products, dung, urine and litters, which converts into farmyard manure maintains sustainable positive natural cycle that improves environment by producing and maintaining more greens and control pollution. Dairy farming creates employment to work at shed, feeding, housing etc. It also creates employment at dairy cooperative for technical work, accounting, managing etc. An employer is also a good communicator through which people are in contact to get services. At last, all these directly and indirectly make an effect to the society.

\section{MATERIALS AND METHODS}

The qualitative and quantitative data were collected from the 224 dairy farmers of MPC, Mahuli. Primary data were collected from dairy cooperative, milk producers and secondary data from the various sources of published reports. In primary data, questionnaire, interview schedule as well as field observation were applied.

Questionnaire for primary data comprised of dairy husbandry, feeding, milking, socio-economic impact, care and management system, transport of the milk, hygiene and sanitation, daily activities of farmers and employees at cooperative. The data processing was carried out after the collection from the field and was analyzed by using descriptive and analytical tools. The situation analysis before and after intervention of cooperative was carried out based on the interview and questionnaire obtained from related farmers in the same community which provided the picture for the evaluation of major impacts on community of Mahuli, Saptari. 


\section{RESULT AND DISCUSSION}

The discussion on the basis of the collected data is divided into different subheadings.

\section{Occupation to the respondents}

People of respondent family were mainly engaged in livestock farming, studying, agriculture, service and labour as reflected in Table-1.

Table 1: Different Occupation of Respondent Family (5 Year and Above Age)

\begin{tabular}{llcccccc}
\hline \multirow{2}{*}{ SN } & \multirow{2}{*}{ Occupation } & \multicolumn{2}{c}{ Male } & \multicolumn{2}{c}{ Female } & \multicolumn{2}{c}{ Total } \\
\cline { 3 - 7 } & & Number & Percent & Number & Percent & Number & Percent \\
\hline 1. & Agriculture & 18 & 14.5 & 21 & 21 & 39 & 17.4 \\
2. & Service & 7 & 5.7 & 2 & 2 & 9 & 4.0 \\
3. & Livestock & 55 & 44.4 & 51 & 51 & 106 & 47.3 \\
4. & Student & 42 & 33.8 & 26 & 26 & 68 & 30.4 \\
5. & Labour & 2 & 1.6 & 0 & 0 & 2 & 0.9 \\
& Total & 124 & 100 & 100 & 100 & 224 & 100 \\
\hline
\end{tabular}

Source: Authors' computation

The total engaged farmers (above 5 year of age) were 224 (male 124 and female 100). Most of the population was engaged in livestock farming (47.3\%). However, least people $(0.9 \%)$ were doing labour work. Regarding agriculture, female percentage (21\%) was more than male (14.5\%) although its contribution was third largest $(17.4 \%)$ in total percentage. Likewise, male student was more (33.8\%) than female $(26 \%)$ but its contribution was second largest (30.4\%) in total.

\section{Income Source}

Distribution of respondent by income and income sources is as given in Table-2.They were mainly involved in crops, cash crop, dairying, goat farming and service.

Table 2: Distribution of Respondent by Income \& Income Sources (Rs. 000)

\begin{tabular}{llllllll}
\hline $\begin{array}{c}\text { Income Range } \\
\text { (Figure in } \\
\text { thousands) }\end{array}$ & \multicolumn{1}{c}{$\mathrm{HH}$} & $\begin{array}{c}\text { Main } \\
\text { crop }\end{array}$ & $\begin{array}{c}\text { Cash } \\
\text { crop }\end{array}$ & Dairy & Goat & Service & Total \\
\hline $0-40$ & $7(14)$ & $1.7(0.7)$ & $28(10.6)$ & $187(71.3)$ & $46(17.5)$ & - & $262.7(100)$ \\
$40-80$ & $26(52)$ & $86(5.8)$ & $180(12.2)$ & $924(62.3)$ & $294(19.8)$ & - & $1484(100)$ \\
$80-120$ & $8(16)$ & $42(6.9)$ & $33(5.5)$ & $355(58.4)$ & $99(16.3)$ & $78(12.9)$ & $607(100)$ \\
$120-160$ & $3(6)$ & - & $15(3.5)$ & $286(68.2)$ & $65(15.4)$ & $54(12.9)$ & $420(100)$ \\
$160+$ & $6(12)$ & $24(1.8)$ & $193(14.6)$ & $504(38.1)$ & $127(9.6)$ & $478(36)$ & $1335(100)$ \\
& $50(100)$ & $153(3.7)$ & $449(11.0)$ & $2256(55.0)$ & $631(15.5)$ & $610(14.9)$ & $4108.7(100)$ \\
\hline
\end{tabular}

Source: Authors' calculation. Note: Figure in parenthesis is percentage. $\mathrm{HH}=\mathrm{Household}$ 
The income range group (40-80 thousand) of highest household (52\%) was highly dependent on dairy farming $(62.3 \%)$. On an average dairy has contributed the highest income $(55.1 \%)$ out of all the five income sources. The income from the facility of irrigated land for major crop of rice and wheat contributed relatively a lowest (3.7\%) percentage out of the all income sources. Regarding the income from goat farming and services/wage, the contribution was almost equal. Similarly, respondents of having pakho land with cash crop of maize and mustard found to be shared $11 \%$ in total which indicated income group of more than 160 thousand a high contribution $(14.6 \%)$ than that of others.

The same statement of income source were mentioned by Dhanapala (1988) remarking that dairy cooperatives have importance and they play a useful role in promoting rural development, especially they can facilitate the development of rural economics, thus it upgrades standard of living of the poor.

\section{Social Impact}

Cooperative is a common place for the people, who deliver milk in the morning and evening, thus people interact even on a new thing, introduce its communication and thus it is being spread within a short time though it may or may not be adopted in the society. Similarly, if events held at any household, he/she is helped by financially and socially. Niraula (2003) has also agreed that Socio-economic impact of dairy cooperative is significantly positive. Dairy cooperatives have made the farmers to unite in a group, which has made them more social. He adds that income from the milk and livestock farming has made them culturally changed such as with good housing, hygienic toilet, bio-plant, television and education.

\section{Physical Impact}

Physical impact quite changed than before and still it is in a changing process. Figure- 1 shows some of the physical changes that took place in the studied area over the lapse of time. There has been more provision of drinking water (DW), electricity and toilet as well. Biogas was an alternate source of energy that was found $14 \%$ of the respondent.
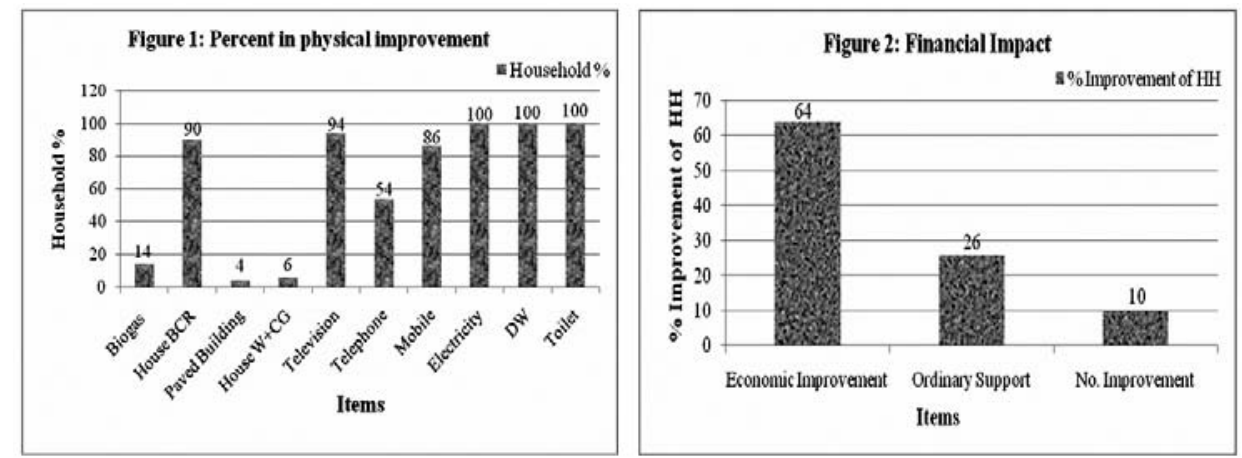
House, made of corrugated (CG) and brick wall is strong and durable than thatched which was replaced by $90 \%$. Television use for entertainment was found among $94 \%$ to the respondents. Regarding telephone and mobile respondents mentioned that they were being gradually promoted among the households.

\section{Financial Impact}

For the financial impact, $64 \%$ respondents were found (Figure-2) having economic progress and $26 \%$ respondent to have the ordinary support from dairy farming. However, nearly $10 \%$ of the respondents were found to have no improvement made by dairy farming.

\section{Economic Impact}

The economic importance of livestock sector, dairy in particular, is well recognized for farmers and people living in rural areas of Nepal. The Agricultural Perspective Plan (APP) of Nepal envisaged dairy sub-sector as a fast growing widely accepted sector which contributes additional income to the farmers for their household expenses. The use of income from dairy in the area of this study is shown in Figure 3.

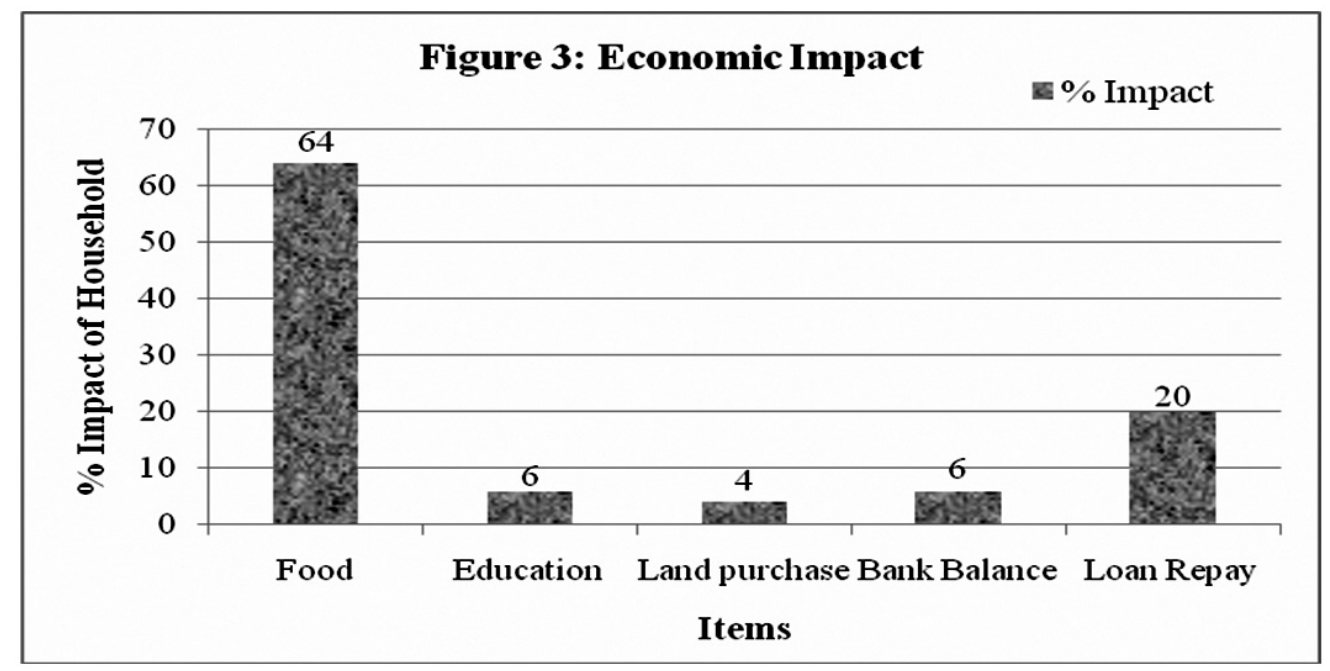

The utilization of dairy income (as shown in Figure 3) was found as expenditure on food, education, land, bank balance and repay loan. Regarding the use of income from dairy farming majority of respondent $(64 \%)$ said it was spent in purchasing food. Likewise $(20 \%)$ used in repaying loan, $(6 \%)$ on education and $(6 \%)$ on bank balance. However, least respondent (4\%) were found utilizing dairy income on land purchase.

Similar income source was reported by Joshi (1990).It has been observed that the establishment of dairy development Corporation (DDC) for milk collection activity 
has profound effect on income of rural milk producers in the project area, and the levels of household income has significantly changed. The change and difference in income between "DDC participating" and "DDC non-participating" farmers were compared and was found that the DDC participants farmers have benefited not only in terms of increased level of income but also it has produced social benefit, improved nutrition and status of the people. It also provided economic, environment and social benefit to the people of project implemented area.

\section{Socio-Cultural Value}

Every farmer has at least 4 dairy animals and has the relation with wealth, prestige and religion. Those who had many milking animals got more income than others. Waste product from the shed is converted into farmyard manure which increases productivity and soil texture reliably than chemical fertilizers. The Hindu's sacred Panchamrit is made by milk products is required to perform religious work. Even every time before cooking, the kitchen is made sacred and clean by cow-dung. Cows have high value at Laxmi Puja, Janai Purnima, Baisakh Purnima and Dhani Purnima in Mansir whereas she buffalo is highly beneficial animal for her sweet milk taste and high protein.

The socio-economic impact of dairy activities in neighbouring VDC where there is no dairy co-operatives is not found so much encouraging as in Mahuli.

\section{CONCLUSION}

Dairy farming is an integral part of rural livelihood which shows the concept of cooperative approach for gaining common goal of farmers. Dairy cooperative is a common venue where farmers meet in the morning and evening daily during milk delivery. So regular meeting have provided them opportunity for mutual harmony and sharing their socio-economic impact. Dairy cooperative makes society organized, harmonized and helpful. Dairy cooperative helps to create awareness in health, sanitation, and education to the farmers. It also helps to promote woman's empowerment program in the society.

\section{Acknowledgement}

Acknowledgement goes to Mr. Puspa Rai Lecturer, Patan Multiple Campus for his guidance and supervision to completion this study work.

\section{References}

Central Bureau of Statistics (CBS), the Government of Nepal (2010). Statistical pocket book of Nepal, 2010.Kathmandu: Author. 
Dhanapala, S.B. (1988). Dairy development through cooperative structure, file:/E:/Internet/ Dairy Development through Cooperative Structure.

FAO (1972). Payment for milk on quality. Rome: Author

Joshi, D.D. (1990). Impact evaluation of dairy development corporation milk collection activity on income rural milk product, FAO, 31- 32

Niroula, C.K. (2003). Socio-economic status and impact of dairy farming among dairy farmers in Budhbare area, Jhapa. An unpublished thesis submitted to the Faculty of Humanities and Social Science in Partial Fulfillment of the Requirements for the Master's Degree in Geography, Central Department of Geography TU, 102-105.

Prakash, D. (2007). Report on education makes cooperatives strong and vibrant. Sahakari Sambad, Annual Issue 2007, National Cooperative Development Board (NCDB), Nepal. 17 (2), 5-8.

Shrestha, R.G. (2006). Quality Milk Collection, Constraints and Approach for the stakeholder of National. Dairy Development Board, Hariharbhawan, Pulchowk.

Singh, S.B. (2000). Strategies and alternative approaches for future growth of the livestock sector in Nepal. Proceedings of 3rd National Animal Science convention, Nepal Animal Science Association (NASA), Nepal, 1-2.

Upadhyaya, R.M., Joshi, D.D., \& Thapa, T.B. (2001). History of dairy development in Nepal. National Dairy Development Board, Nepal, 5-7. 